Pesq. Vet. Bras. 35(6):579-582, junho 2015 DOI: $10.1590 / \mathrm{S} 0100-736 \mathrm{X} 2015000600016$

\title{
Patterns of parasitism by Amblyomma rotundatum (Ixodidae) on Rhinella schneideri (Bufonidae) in islands of São Francisco River, Minas Gerais, Brazil ${ }^{1}$
}

\author{
Hermes Ribeiro Luz ${ }^{2}$, João Luiz Horacio Faccini ${ }^{2 *}$ and Hélio Ricardo da Silva ${ }^{3}$
}

\begin{abstract}
Luz H.R., Faccini J.L.H. \& Silva H.R. 2015. Patterns of parasitism by Amblyomma rotundatum (Ixodidae) on Rhinella schneideri (Bufonidae) in islands of São Francisco River, Minas Gerais, Brazil. Pesquisa Veterinária Brasileira 35(6):579-582. Departamento de Parasitologia Animal, Instituto de Veterinária, Universidade Federal Rural do Rio de Janeiro, Seropédica, RJ 23890-000, Brazil. E-mail: faccinijlh@globo.com

We sampled ticks from specimens of the rococo toad Rhinella schneideri by flannel dragging on two Islands located in the São Francisco River near the Três Marias hydroelectric dam, southeastern Brazil. A total of 120 toads was examined, of which 63 (52.5\%) were parasitized only by Amblyomma rotundatum totaling 96 larvae, 163 nymphs and 134 females. The burden of parasitism ranged from one to 43 ticks, with a mean intensity of infestation of $6.2 \pm 5.5$ ticks per host. The tick $A$. rotundatum exhibited highly aggregated distribution. Peak abundance of larvae and nymphs occurred in the dry season (May to September), whereas peak abundance of females occurred in the wet season (October to April). We collected most ticks near the head and hind limbs of $R$. schneideri. The finding of two engorged $A$. rotundatum nymphs in the same resting places of two toads and the absence of this species in the dragged areas suggest a nidicolous behavior at the studied site.
\end{abstract}

INDEXS TERMS: Amblyomma rotundatum, Rhinella schneideri, aggregation, parasite-host relations, Brazil.

RESUMO.- [Parasitismo por Amblyomma rotundatum (Ixodidae) em Rhinella schneideri (Bufonidae) em duas ilhas do Rio São Francisco, próximas à represa de Três Marias, Minas Gerais.] Sapos da espécie Rhinella schneideri foram capturados e examinados para coleta das fases parasitárias, assim como arrasto de flanela para coleta das fases de vida livres de carrapatos em duas ilhas localizadas no rio São Francisco, próximas à represa Três Marias, região sudeste do Brasil. No total, 120 indivíduos foram examinados, dos quais $63(52,5 \%)$ estavam parasitados por Amblyomma rotundatum totalizando 96 larvas, 163 ninfas e 134 fêmeas. A abundância do parasitismo variou de $1 \mathrm{a}$ 43 carrapatos, com uma intensidade média de infestação de 6,2 $\pm 5,5$ carrapatos/hospedeiro. A infestação por A. ro-

\footnotetext{
${ }^{1}$ Received on November 20, 2014.

Accepted for publication on July 3, 2015.

${ }^{2}$ Departamento de Parasitologia Animal, Instituto de Veterinária, Universidade Federal Rural do Rio de Janeiro (UFRRJ), Seropédica, RJ 23890000, Brazil. *Corresponding author: faccinijlh@globo.com

${ }^{3}$ Laboratório de Herpetologia, Departamento de Biologia Animal, Instituto de Biologia, UFRRJ, Seropédica, RJ. E-mail: heliorsilva@gmail.com
}

tundatum apresentou uma distribuição altamente agregada. 0 pico de abundância de larvas e ninfas ocorreu na estação seca (maio a setembro ), enquanto o pico de abundância de fêmeas ocorreu na estação chuvosa (outubro a abril). A maioria dos carrapatos foi coletada na região da cabeça e membros posteriores. A presença de duas ninfas ingurgitadas de $A$. rotundatum nos mesmos lugares de descanso de dois sapos e a ausência desta espécie na coleta por arrasto de flanela sugere um comportamento nidicola no local estudado.

TERMOS DE INDEXAÇÃO: Amblyomma rotundatum, Rhinella schneideri, distribuição agregada, relação parasitária, Brasil.

\section{INTRODUCTION}

Ticks are arthropods that parasitize amphibians, reptiles, birds and mammals. In Brazil, there has been a steady increase in the number of studies on tick-host relations and wild birds and mammals in the last 10 years. However, few studies have addressed cold - blooded animals (reptiles and amphibians), with sporadic reports describing the occurrence of ticks in small host samples. To date, six spe- 
cies of ixodids have been recorded on toads of the family Bufonidae (Luz \& Faccini 2013) and Amblyomma rotundatum_Koch, 1844 is commonly recorded on toads in Brazil. However, most publications on this species only report data on occurrence, prevalence of infestation (PI) and mean intensity of parasitism (MIP) in small samples of hosts (Luz \& Faccini 2013). Exceptions are the papers from Woehl (2002) who found a PI of $19.2 \%$ and MIP of 7.4 ticks/toad surveying 125 specimens of Rhinella icterica (= Bufo ictericus) (Spix, 1824) in the southern region of the country, Santos et al. (2002) who found a PI of $61.6 \%$ for A. rotundatum on 73 specimens of Rhinella schneideri (= Bufo paracnemis) (Werner, 1894) in the northern region and Ahid et al. (2009) found a PI of $4.95 \%$ and MIP of 2.8 ticks/toad surveying 101 specimens of Rhinella marina (= Bufo marinus) (Linnaeus, 1758) in the northern region, all of them without additional analysis of the host-tick association.

Although there are reports on pathogens transmitted by $A$. rotundatum to toads (Petit et al. 1990, Lainson et al. 2007) there are no records of pathogens transmitted to $R$. schneideri. In addition, the occurrence of Rickettsia bellii in A. rotundatum has been reported by Labruna et al. (2004).

Both the rococo toad $R$. schneideri and the tick A. rotundatum are widely distributed throughout Brazil. The former occurs from the southern portion of the state of Espírito Santo (southeastern region) to the northern portion of the state of Paraná (southern region) (Baldissera Jr. et al. 2004) and the latter occurs from the state of Amazonas (northern region) to the state of Rio Grande do Sul (southern region) (Luz \& Faccini 2013).

The aim of the present study was to report the results of a survey on the relationship between A. rotundatum and $R$. schneideri in two river islands resulting from the construction of the Três Marias hydroelectric power plant located in the São Francisco River, state of Minas Gerais, southeast Brazil.

\section{MATERIALS AND METHODS}

The study was conducted in two islands resulting from the construction of the Três Marias hydroelectric power plant located in the São Francisco River, state of Minas Gerais, Brazil. The islands are isolated from each other by the river, which is approximately 2.5 kilometers in width between them (Fig.1). Both islands are dominated by savanna-like vegetation.

Toads were captured in both islands (Fig.2) using two sampling methods: i) pitfall traps, with seven 40-liter plastic buckets arranged linearly $10 \mathrm{~m}$ apart and connected by a fence guide made of a black plastic sheet $30 \mathrm{~cm}$ in height with the lower end buried into the ground. The traps were checked from 09:00 to 12:00 hour the day after deployment, ii) visual search and manual capture of toads in all accessible habitats from 18:00 to 23:00 hours. Each collection trip lasted four days/month from January to December 2009 , totaling 48 field trips. We used boats on loan from IBAMA/ ICMBio to travel between islands. All toads captured were thoroughly examined as quickly as possible, identified according to Lema \& Martins (2011) and returned to their habitats to avoid injury. All ticks (larvae, nymphs and females) found on the toads were collected. We also attempt to collect free-living stages by flannel dragging. All ticks were stored in glass jars containing $70 \%$ ethanol for subsequent identification according to Keirans \& Oliver (1993) and Onofrio et al. (2006). Voucher specimens were deposited at the University of Sao Paulo (Brazil), accession number CNC-USP 2399. This study was carried out with permission of the Brazilian environmental agency IBAMA (protocol number: 21304-1/2009).

The precipitation data were obtained from a meteorological station located approximately 15 kilometers from the collection sites (Fig.1). The classification of the dry (May to September) and wet (October to April) seasons was based on a publication of the Brazilian Agricultural Research Corporation (Embrapa <http://www. cpac.embrapa.br/unidade/ocerrado/) > Accessed in June 2012.

We assessed possible differences between the dry and wet seasons by the chi-square test using the Biostat 5.0 program (Ayres et al. 2003), at the $5 \%$ level of significance ( $p<0.05)$. We also quantify the degree of aggregation by the Poulin's Index of Discrepance "D" which range from zero (no aggregation) to unity (total aggregation) (Rózsa et al. 2000).

\section{RESULTS}

Overall, 63/120 (52.5\%) of the toads examined were parasitized by Amblyomma rotundatum, with a mean intensity of infestation of $6.2 \pm 5.5$ ticks per host. We collected 393 ticks: 96 larvae (24.4\%), 163 nymphs (41.5\%) and 134 females (34.1\%). Tick burdens ranged from 1 to 43 ticks, with $22.2 \%$ toads infested with one or two ticks. A. rotundatum

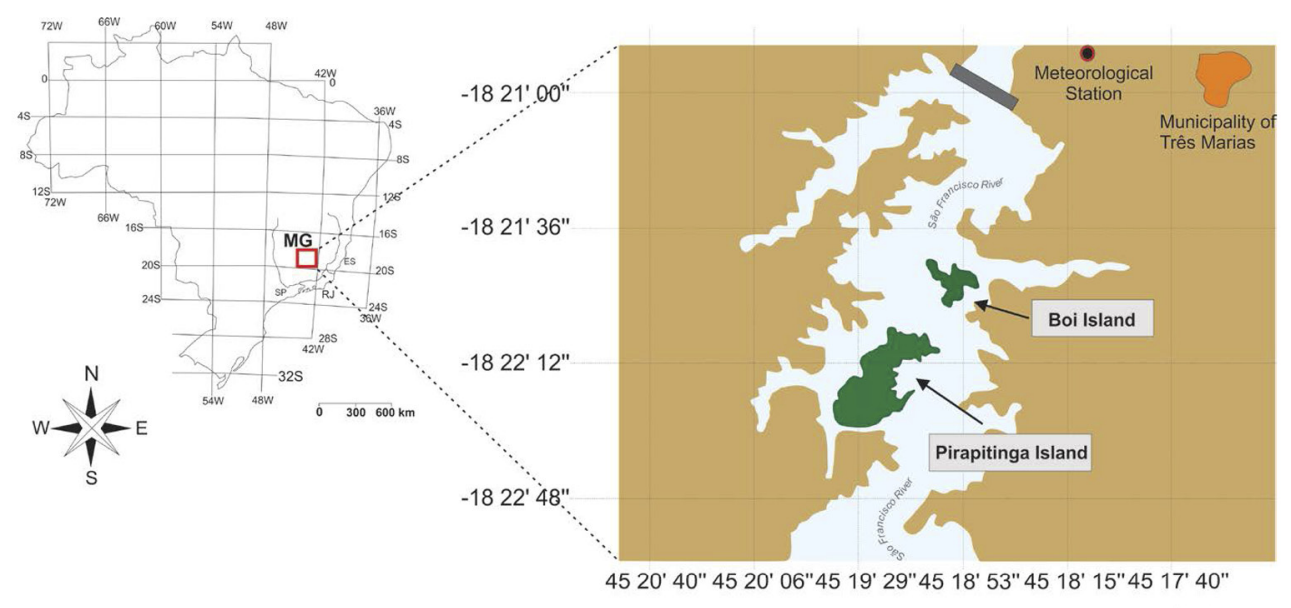

Fig.1. Location of the two study areas in the São Francisco River, state of Minas Gerais, Brazil. 

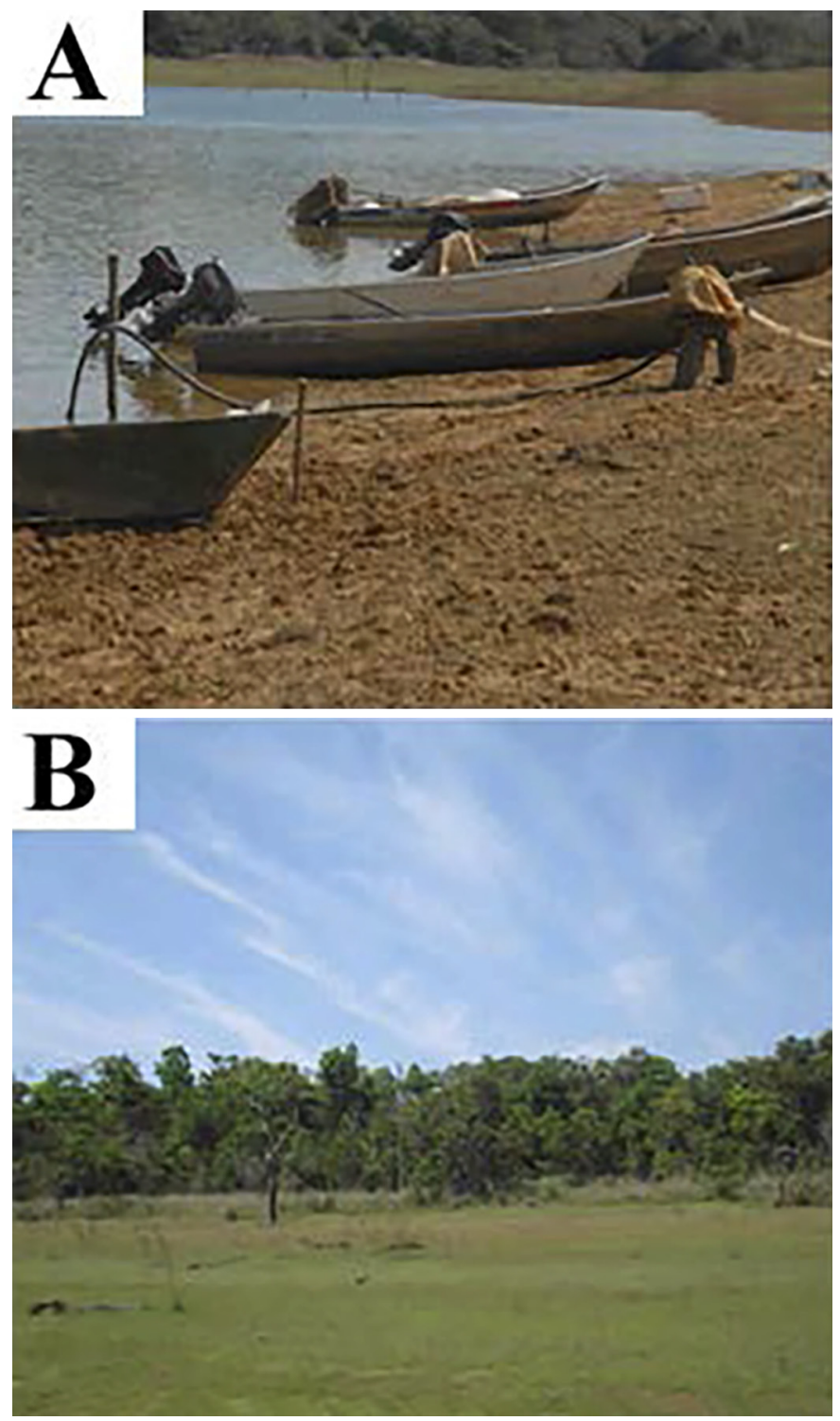

Fig.2. Sites of captures of toads. (A) Island of Boi and (B) Island of Pirapitinga, Minas Gerais.

exhibited highly aggregated distribution $(\mathrm{D}=0.746)$, with $57 / 120(47.5 \%)$ toads without ticks.

Lesions at the site of the tick bite were observed on the majority of infested hosts

[84/120 (70\%)] as a consequence of parasitism by all stages (larva, nymph and females), with more severe lesions caused by engorged females. One of the hosts had focal bleeding immediately after the removal of fully engorged females (Fig.3).

Ticks were collected from several regions of the host body, occurring most frequently near the head $[n=60$ (23 larvae, 20 nymphs and 17 females)] and hind limbs [ $\mathrm{n}=72$ (15 larvae, 9 nymphs and 48 females)].

We captured 369 free-living ticks: 68 larvae, 46 nymphs and 255 adults. Regarding the adults, Amblyomma sculptum (= A.cajennense in part) Berlese, $1888(\mathrm{n}=132)$ was the most common species, followed by Amblyomma parvum Aragão, 1908 (n=97), Amblyomma dubitatum Neumann,

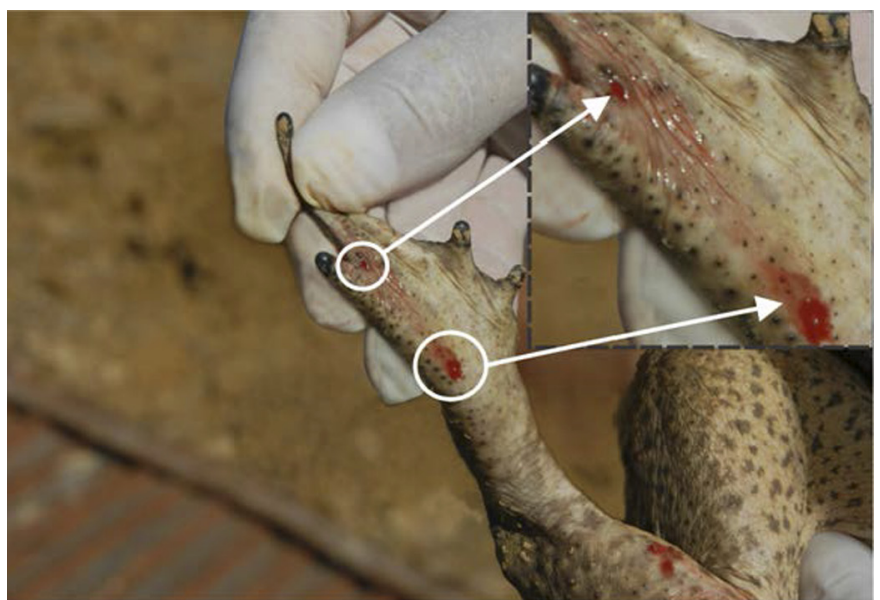

Fig.3. Bleeding on ventral side of right hind limb of a Rhinella schneideri immediately after removal of an engorged Amblyomma rotundatum female.
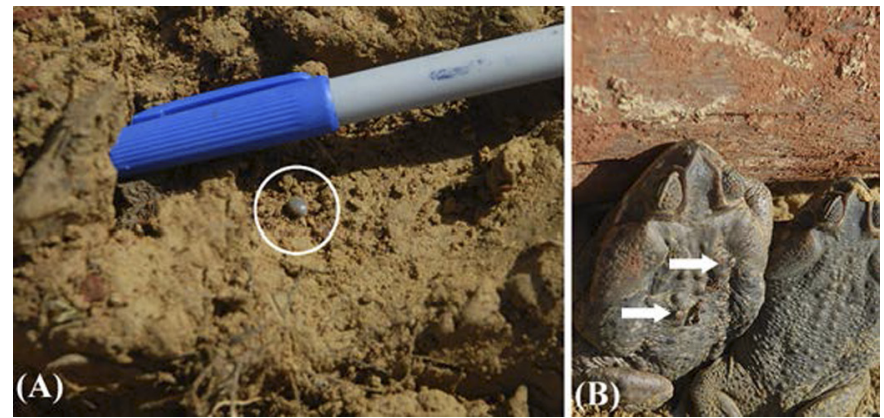

Fig.4. (A) One engorged Amblyomma rotundatum nymph (circle) found on the ground, and (B) two partially engorged females (arrow) found on Rhinella schneideri at same diurnal resting places.

1899 ( $\mathrm{n}=14)$, Amblyomma ovale Koch, 1844 (n=7) and Amblyomma coelebs Neumann, $1899(\mathrm{n}=5)$. The nymphs were identified as A. sculptum (n=27), A.parvum (n=12), A. dubitatum $(\mathrm{n}=3)$, A ovale and A. coelebs $(\mathrm{n}=2$ each). All larvae were identified as Amblyomma spp. No specimens of $A$. rotundatum were captured by dragging but two engorged $A$. rotundatum nymphs were seen in the same diurnal resting places of two toads (Fig.4).

Overall, 81/120 (67.5\%) toads as well as 50/63 (79.4\%) infested specimens were more abundant in the wet season (mainly from December to April) $(p<0.0001)$ and we collected most full engorged females only from December to April (wet season). However, larvae and nymphs were more abundant in the dry season (May to August).

\section{DISCUSSION}

The tick Amblyomma rotundatum was the only species of tick identified parasitizing toads at both sites, although other species, such as Amblyomma dissimile Koch, 1844 , Amblyomma sculptum, Amblyomma goeldii Neumann, 1899, Amblyomma fuscum Neumann, 1907, and Amblyomma humerale Koch, 1844 (Luz \& Faccini 2013) have also been recorded parasitizing toads in Brazil. As expected we did not find males of this obligate parthenogenetic tick species 
(Martins et al. 2014). Results obtained in this study are similar to those obtained by Santos et al. (2002) in the state of Pernambuco, northeast Brazil, concerning the prevalence of females and nymphs but rather different regarding the prevalence of larvae. This difference may be due to the period of collection of ticks because about $90 \%$ of the parasitized hosts were captured in the months from October to December by Santos et al. (2002) while samples for this study were collected over one year.

Tick distribution on Rhinella schneideri is quite similar to R. marina (Lampo \& Bayliss 1996) and is characterized by high level of aggregation and prevalence and low intensity of parasitism. According to Lampo \& Bayliss (1996), this scenario suggests high transmission rates modulated by density-dependent mechanisms.

Lesions caused by ticks on toads, such as those seen in the present survey can lead to blood and weight loss, secondary skin infections and behavioral modifications in hosts Luz et al. (2012). Moreover, according to Smith et al. (2008), a toad infested with 33 specimens of $A$. rotundatum was moribund when found and died shortly thereafter. In an experimental infestation carried out on two toads by Luz et al. (2012), one toad was sacrificed at the end of the experiment due to extreme weakness. According to Lampo \& Bayliss (1996) and Smith et al. (2008), ticks would play an important role in regulating toad populations. However, further research is needed to support this hypothesis.

The most infested parts of the hosts were head and hind limbs although we collected ticks in virtually all areas of the host bodies. Santos et al. (2002) and Smith et al. (2008) also report similar body distribution of A. rotundatum in Rhinella granulosa (= Bufo granulosus) Spix, 1824) and R. schneideri.

The absence of $A$. rotundatum during flannel dragging supports the findings of Szabó et al. (2007) and Cançado et al. (2008) who also collected $A$. rotundatum from toads but not from dragging in different ecological regions. Based on these results and the finding of two engorged nymphs in the same habitat as the hosts, which seek refuges to avoid dehydration during the day, we assume that $A$. rotundatum exhibits nidicolous behavior at the studied site.

The occurrence of fully engorged females, from December to March (wet season) may be explained by toads behavior. It is well known that toads increase foraging activity in the wet season (Giaretta et al. 1999) which may favors encounters with ticks.

Acknowledgements.- This study was supported by the National Council of Scientific and Technological Development (CNPq) through grants for JLH Faccini and HR Luz.

\section{REFERENCES}

Ahid S.M.M., Fonseca Z.A.A.S., Ferreira C.G.T., Martins T.F. \& Oliveira M.F. 2009. Parasitismo de Amblyomma rotundatum (Koch) (Acari: Ixodidae) em Bufo marinus (Linnaeus) (Anura: Bufonidae), em Mossoró, Rio Grande do Norte, Brasil. Revta Bras. Zoociências 11:153-156.
Ayres M., Ayres J.R.M., Ayres D.L. \& Santos A.S. 2003. BioEstat 3.1: aplicações estatísticas nas áreas das ciências biológicas e médicas. Soc. Civ. Mamirauá, Brasilia, DF.

Baldissera J.R.F.A., Caramaschi U. \& Haddad C.F.B. 2004. Review of the Bufo crucifer species group, with descriptions of two new related species (Amphibia, Anura, Bufonidae). Arq. Mus. Nac., Rio de J., 62:255282.

Cançado P.H.D., Piranda E.M., Mourão G.M. \& Faccini J.L.H. 2008. Spatial distribution and impact of cattle-raising on ticks in the Pantanal region of Brazil by using the CO2 tick trap. Parasitol. Res. 103:371-377.

Giaretta A.A., Facure K.G. \& Sawaya R.J. 1999. Diversity and Abundance of Litter Frogs in a Montane Forest of Southeastern Brazil: Seasonal and Altitudinal Changes. Biotropica 31:669-674.

Keirans J.E. \& Oliver J.H. 1993. First description of the male and redescription of the immature stages of Amblyomma rotundatum (Acari: Ixodidae), a recently discovered tick in the USA. J. Parasitol. 79: 860-865.

Labruna M.B., Whitworth T., Bouyer D.H., McBride J., Camargo L.M.A., Camargo E.P., Popov V. \& Walker D.H. 2004. Rickettsia bellii and Rickettsia amblyommii in Amblyomma Ticks from the State of Rondônia, Western Amazon, Brazil. J. Med. Entomol. 41:1073-1081.

Lampo M. \& Bayliss P. 1996. The impact of ticks on Bufo marinus from native habitats. Parasitology 113: 199-206.

Lainson R., Souza M.C. \& Franco C.M. 2007. Natural and experimental infection of the lizard Ameiva ameiva with Hemolivia stellata (Adeleina: Haemogregarinidae) on the toad Bufo marinus. Parasite 14:323-328.

Lema T. \& Martins L.A. 2011. Anfíbios do Rio Grande do Sul: catálogo, diagnoses, distribuição, iconografia. Edipucrs, Porto Alegre. 235p.

Luz H.R., Faccini J.L.H., Pires M.S., Da Silva H.R. \& Barros-Battesti D.M. 2012. Life cycle and behavior of Amblyomma rotundatum (Acari: Ixodidae) under laboratory conditions and remarks on parasitism of toads in Brazil. Exp. Appl. Acarol. 60:55-62.

Luz H.R. \& Faccini J.L.H. 2013. Parasitismo por carrapatos em Anuros no Brasil: revisão. Vet. Zootec. 20:100-111.

Martins T.F., Venzal J.M., Terassini F.C., Marcili F.B., Camargo L.M.A., Barros-Battesti D.M. \& Labruna M.B. 2014. New tick records from the state of Rondônia, western Amazon, Brazil. Exp. Appl. Acarol. 62:121-128.

Onofrio V.C., Labruna M.B., Pinter A., Giacomin F.G. \& Barros-Battesti D.M. 2006. Família Comentários e chaves para as espécies do gênero $\mathrm{Am}$ blyomma, p.56-113. In: Barros-Batestti D.M., Arzua M. \& Bechara G.H. (Eds), Carrapatos de Importância Médico-Veterinária da Região Neotropical: um guia ilustrado para identificação de espécies. Vox/ICTTD-3/ Butantan, São Paulo. 223p.

Petit G., Landau I., Baccam D. \& Lainson R. 1990. Description et cycle biologique d'Hemolivia stellata, n.g., n.sp., hemogrégarine de Crapauds brésiliens. Ann. Parasitol. Hum. Comp. 65:3-15.

Rózsa L., Reiczigel J. \& Majoros G. 2000. Quantifying parasites in samples of hosts. J. Parasitol. 86:228-232.

Santos E.D., Botelho M.C.N. \& Oliveira J.B. 2002. Ectoparasitos de anfíbios anuros (Anura: Bufonidae) capturados na estação ecológica do Tapacura, São Lourenço da Mata, Pernambuco, Brasil. Entomol. Vectores 9:105113.

Smith R.L., Schnack J.A., Schaefer E.F. \& Kehr A.I. 2008. Ticks, Amblyomma rotundatum (Acari- Ixodidae), on toads, Chaunus schneideri and Chaunus granulosus (Anura: Bufonidae), in northern Argentina. J. Parasitol. 94:560-562.

Szabó M.P.J., Olegário M.M.M. \& Santos A.L.Q. 2007. Tick fauna from two locations in the Brazilian savannah. Exp. Appl. Acarol. 43:73-84.

Woehl J.R.G. 2002. Infestação de Amblyomma rotundatum Koch (Acari, Ixodidae) em sapos Bufo ictericus Spix (Amphibia, Bufonidae): novo registro de hospedeiro. Revta Bras. Zool. 19:329-333. 